\title{
Institutional Aspects on Bus Rapid Transit Systems Implementation in Mexico City, Estado de Mexico and León Guanajuato
}

\author{
Fernando Lámbarry Vilchis (Corresponding author) \\ Escuela Superior de Ingeniería Mecánica y Eléctrica / Escuela Superior de Comercio y Administración, Instituto \\ Politécnico Nacional \\ E-mail: flambarry@ipn.mx \\ Luis Arturo Rivas Tovar \\ Centro de Investigación en Ciencias Administrativas de la Escuela Superior de \\ Comercio y Administración, Instituto Politécnico Nacional \\ E-mail: larivas@ipn.mx \\ Mara Maricela Trujillo Flores \\ Escuela Superior de Comercio y Administración, Instituto Politécnico Nacional \\ E-mail:martruj@aol.com
}

Received: September 7, $2010 \quad$ Accepted: September 20, 2010 doi:10.5430/jms.v1n1p93

\begin{abstract}
The paradigm of bus rapid transit as a mean of public transportation has been studied from different perspectives by renowned international researchers and, although there is a consensus in its implementation because of the operational institutional traditional structures toward a public-private participation scheme,there is few specialized literature that analyzes these institutional aspects: the actors involved, the new system organization and the legal norms of the new transport system. This research through study cases is aimed to compare institutional aspects between the Leon Guanajuato's Optibus, the Mexico's City Metrobus and the State's of Mexico Mexibus, which represents the bus rapid transit systems implementation, in order to identify in each of them the actors involved, their stockholders and contractual options, the organization and the legal framework that provides certainty to the systems' institutional scheme. Key words: Rapid transit bus, Institutional aspects, Actors involved, System organization, Legal regulations.
\end{abstract}

\section{Introduction}

Public transport studies have been approached from different perspectives, Van Egmond, Nijkamp and Vindigi (2003), conclude that it is required to improve the local public transport service efficiency through drastic changes in the mass transit systems organization, which involves creating a regulation that reconciles the market interests and high quality services focused on citizens. Winston (2000), proposes the privatization due to government technical inefficiency at investment and public transport regulation. Humphrey (1979) summarizes that on a successful public transport policy the coordination and cooperation among government agencies are crucial so that it will be possible to finance infrastructure and massive transportation systems.

The public transport paradigm (Curitiba, Brazil, 1974) known as Bus Rapid System (BRT), has features that place them in the mass transport systems family, in which are placed systems such as the subway, light rail and tram, which is relevant due to the BRT systems are competitive in performance against the subway, but most of all in terms of insertion flexibility.

Topic World Experts, have focused on study and research extensively the BRT concept on topics such as the overall system (Wright, 2003, Wright and Fjellstrom, 2003; Hook, 2005), the demand modeling (Ortúzar and Willumsen, 2002), the vehicle technology and the systems pricing (United States Federal Transit Administration, 2001), the system evaluation (Litman, 2006), the regional and global comparison among them (Hidalgo et al, 2007; Menckhoff, 2007; Ardila 2004) and, systems planning and regulation (Ardila, 2004; Meakin, 2002; Levinson Zimmerman et al, 2003).

Likewise, the topic has been approached by organizations within the most important studies are those developed by: 
Institute for Transportation and Development Policy, 2007, Embarq The WRI Sustainable Transport Centre, 2005, German Technical Cooperation / Sustainable Urban Transport Project , 2003), which point out the importance of a radical change in the institutional framework and the existing business plan structure by the current concessionaires, resulting in corporate stock schemes with public and private participation. See Table 1.

The above information is the result of an extensive compilation and research of BRT systems in the world by the authors and organizations referred, which ultimately result in general guidelines for planning and implementation of systems, and can be drawn from them, the required institutional aspect between the actors involved and their redefinition of responsibilities.

\subsection{BRT Concepts}

The Institute for Transportation and Development (ITDP) (2007) notes that the BRT term converges under different names around the world: Bus Rapid Transit Systems, High Capacity Bus Systems, High Quality Bus Systems, Metro-Bus, surface Metro, Express Bus Systems, Bus-Based Systems, Transportation Integrated Systems, Bus Rapid Mass Transit. Similarly the definitions that frame such term are in Table 2.

In the referred authors definitions, there is a trend that suggests that systems of bus rapid transit have more in common with rail-based systems in terms of operational performance and passenger service, being the fact that BRT systems can usually provide a transport service quality at a cost that most cities can afford the main difference between them.

\subsection{Typology}

The ITDP (2007), summarizes the wide variety of systems currently in operation which form a possibilities spectrum (Figure 1), mostly due to local factors that affect the attributes and characteristics of BRT, including local and cultural preferences, population density, climate, geography, topography, availability of financial resources, local technical capacity, companies and institutional structures, and perhaps most important, the degree of political will to implement them.Determine what specifies a BRT would seem system quantitative characteristics, such as system capacity, average speed of vehicles and the size of the network as factors of a high quality service. However, in publications and researchers such as Menckhoff (2005), Levinson et al, (2003), Rebelo et al (2003) and Mereilles (2000), it is known that many key features in service quality for public transport are partly qualitative nature, which include: ease of access to the system, stations and vehicles comfort, sense of security, clarity of the maps, friendly drivers and personal, among other things.

$<$ Figure 1 about here $>$

\subsection{Cities with BRT systems}

The BRT system technology transfer from Latin America to other nations has made this system one of the most remarkable examples of technology transfer from the underdeveloped south to the developed north (Iracheta, 2006). Table 3 shows until 2007, cities with BRT systems around the world.

In Mexico, due to the benefits obtained by implementing Optibus system of the city of Leon, the Metrobus in Mexico City, Transmetro in Monterrey and Macrobús in Guadalajara, is projected as a national development policy at all the country (Table 4), a sustainable mass transport strategy based on bus rapid transit.

Despite the importance of these systems as a mass public transport alternative as referred by international and Mexico projects, there is little specialized literature to analyze and compare the institutional aspects required by the new transport system.

This research through study cases is aimed to compare the institutional aspects between Optibus in the City of Leon Guanajuato, Metrobus in Mexico City and Mexibus in Estado de Mexico, which represents the implementation of bus rapid transit systems.

\section{Method}

This study is a descriptive and qualitative documentary research, in which it was decided to study the institutional aspects in the implementation of systems of rapid transit buses in Mexico City, Estado de Mexico and Leon Guanajuato.The criteria that defined this selection for the city of León is being the first implemented system of its kind in Mexico. For Mexico City and the Estado de Mexico is constituting the Metropolitan Area, which form the economic, political and social center of the country.The study uses the case method and involved a documentary review and structured interviews with experts in the field to identify the variables, in this context, documents prepared by international organizations (Institute for Transportation and Development Policy, Center for Sustainable Transport, German Technical Cooperation / Sustainable Urban Transport Project) who model the systems planning and implementation of bus rapid transit were studied, it is noted that the Sustainable Transport Centre has worked BRT 
intensively in the Mexican cultural context and therefore in its proposed model the stage of institutional aspects was considered as a basis.

The study subjects, made up mostly by official documents of the Mexico City and Estado de Mexico transport ministries in addition to the Mobility General Direction of the León city, such as government gazettes and government programs , which provided documentary evidence in terms of the BRT systems description and organization (including the actors involved, their participation and the contractual option), plus the United Mexican States Political Constitution revision, and the Local Roads and Transport Regulations, in order to analyze the relevant legal framework to these systems. Additionally, reports and presentations at national and international conferences were examined to gather information concerning the BRT organization that considers aspects such as: as the managing organism, the participants collaboration type, the functional structure and form of financing. BRT systems operating companies publications were contemplated, BRT complement information

Based on this, the defined investigation variables and analysis categories are:

- Actors involved: participants contractual options, shareholders identification.

- System Organization: Managing organism, type of participation, functional structure and form of financing.

- Legal Framework: Regulations, regulatory entity, management, transport planning and control as a public service, legal certainty on concessions.

As research limitations, the authors stand out the slight existing information systems about rapid transit buses, the most notorious case is the Optibus, that being the oldest in Mexico, has no relevant research publications or dissemination of them. Mexibus system, although is currently in project, the available consulted information is fully official, generated by the government. The mentioned cases make somehow complicated the definition, documentation and operationalization of the variables mentioned in theoretical models.

\section{Analysis}

Here are the three rapid transit busses systems studied: The Optibús case, Leon Guanajuato, the Metrobus case, Mexico City and the Mexibus case, Estado de Mexico, to identify the actors involved in each of them, their shareholders and contractual options, the organization and the legal framework that provides certainty to the institutional BRT scheme.

\subsection{León Guanajuato: Optibus case}

In 1994 the Urban Transport Coordinator of the City was formed, as a Civil Society, which reconciles and unites the interests of urban transport executives in the city of León, working among the authorities and civil society to improve the service through an integrated transport system of articulated buses, called Optibús.

\subsubsection{System description: Optibús}

The new transport system proposed, eliminated the old operation habit the "man truck "scheme and anonymous societies were formed in which permittees, instead of having concessions and units, theyown shares, permittees stop worrying about whether their unit goes out to work or not, since all the company profits are shared equitably and proportionally among the partners and a portion of incomes are saved for units renewal and maintenance.

The Optibús operating since 2003 (September 26th, 2003), has integrated facilities, which consist of terminal or transfer stations (in total 4 located at the cardinal points of the city) and intermediate or stopping stations also it should be noted that for the routes, the system divided the current routes into three categories, two of which integrate the routes already existing (feeders with 31 routes and six more auxiliaries) and a new category, served by the "Integrated Transport System Optibús" Optibús (trunk routes with 51 stations and 35 kilometers of exclusive lanes).

\subsubsection{Actors involved}

In 2002, the thirteen companies that comprise the Urban Transport Coordinator of Leon decided to participate in the Integrated Transport System (SIT), see Table 5

The background to this project comes up to the Full Plan for Urban Transport (PITUL), a proposal from the Municipal Administration. In August of that year more than a company for operating trunk routes was decided to be formed, which gave rise to four new organizations (http://www.pagobus.com/optibus.html 03,23,09):1.Red Optibús Norte, S.A. de C.V. 2. Red Optibús Sur, S.A. de C.V.3.Red Integral Optibús, S.A. de C.V. y 4. Red Optibús Oriente, S.A. de C.V.

\subsubsection{System Organization}

The system features a collection system with prepaid card called Pagobús (Figure 2) to have access to buses and provides the option to do so by cash, same that is used to do transfers between the system routes without additional cost, 
which represents for the user many destination choices with a single payment within the routes integrated network. These revenues are channeled to the operating companies, as rates and formulas previously agreed.

$<$ Figure 2 about here $>$

\subsubsection{Legal framework}

The regulatory framework which gives legal certainty to the concessed companies, is framed in the codes that regulate the public transport planning, management and control, as well as the bids and concessions.Emphasizing the followed:

Organic Law of Public Administration from the State of Guanajuato (LOAPGTO):

Article 141. Municipalities will be responsible for transit service and road on a fixed route.

Municipal Transport Regulations of León, Guanajuato:

Article 2 and 6 Service.The public transport service of municipal competence (collective movement of people) is a priority and strategic element from urban growth and management.

Article 12. The public service of urban and suburban transport, may be provided on first and second class or in other modalities dictated by public interest.

Article 14. To ensure the safety and efficiency of the urban transportpublic service, it will be provided mainly through the integrated route network system.

Article 15. The municipal authorities will establish the implementation of thenecessary infrastructure for the appropriate provision of public transport service. In the case of integrated routing system: transfer stations, intermediate stations or stopping ones and the adaptations to the road infrastructure that may be required.

Article 16. About the enrollment of granted vehicles in the conventional routes system.

Article 17. About the conventional or independent system routes.

Article 20 and 21. Operation of the integrated system routes.

Article 55. About the service vehicles.

Article 100 and 106. About the concessions and permissions.

\subsection{Mexico City: Metrobus case}

Mexico City has three bus rapid transit or transport corridors systems, the so-called Metrobus Insurgentes subsequently expanded its service coverage (Metrobus Insurgentes Sur) and the so called Metrobus Eje 4.

\subsubsection{Metrobus System description}

In this Passenger Public Transport Corridors modality, the first Mexico City corridor was implanted (June 19, 2005), called "Metrobus Insurgentes" in the primary roads identified as Insurgentes Avenue. From March 14, 2008 the system expanded its operating area, this increase was called Corredor Insurgentes Sur, covering a length of $19.7 \mathrm{~km}+8.5 \mathrm{~km}$ expansion, for a total of $28.2 \mathrm{~km}$, stopping in 36 stations and 6 terminals. It has 98 articulated buses and 26 more that joined in the expansion, estimating substantial environmental improvements and reducing a $38 \%$ in travel time and $25 \%$ of road accidents (http://www.metrobus.df.gob.mx/DESCRIPCION. pdf, 2009).

Moreover, as noted by the Distrito Federal Official Gazette No 361 (June 2008, p. 32), the Eje 4 Sur is aroad with a high concentration of public transport supply and demand, being thus bringing is that comes into operation the "Metrobus Eje 4 Sur" corridor with the operation of dealers that provided the service on the passenger collective public transport routes of the actual corridor. The corridor has 36 stations and a length of $18.9 \mathrm{~km}$ that is covered with 72 articulated buses (http://www.setravi.df.gob.mx/metrobus/Metrobus.pdf, 2009)

\subsubsection{Actors involved}

Metrobus Insurgentes: The existing shareholders were individual dealers that formed the Route 2, covering the service on the Insurgentes Avenue. The corridor is regulated by an entity of the Distrito Federal government, known as Organismo Público Descentralizado (Decentralized Public Organism) Metrobús, operating at $25 \%$ by the transport company called Red de Transporte de Pasajeros (RTP) and 75\% by CISA. (CISA Gazette, March 2008). See Table 6.

Metrobus Insurgentes Sur:The Department of Transport and Roads gave the grant and authorization to RECSA and RTP (Setravi, 2008) to give the service in the corridor expansion Metrobus Insurgentes Sur, they operated the routes 1 and 76 on this road. See Table 7.

Metrobus Eje 4: This corridor has 5 companies or agencies offering the service on existing routes, with 72 articulated 
buses that provide the service and distributed as shown in Table 8 (http://www.metro.df.gob.mx, 04, 27, 09).

\subsubsection{System Organization}

On February 25, 2005, the two initial operating companies (RTP and CISA), were a private trust responsible for the administration of total revenues from Insurgentes Metrobus system and its distribution, which at the same time hired a private company to finance, provide and operate the necessary technology platform for the use of a smart card for toll collection. In this process of the project development and implementation, the responsibilities have been shared between the different institutional actors involved. At first instance, the City Government has done the planning, coordination, rectory and management as well as the financing of the construction and maintenance of the corridor infrastructure. While three companies or agencies are responsible for offering the service on existing routes (RTP, CISA and RECSA that joined the expanding corridor Metrobus Insurgentes Sur). and have financially contributed to the units acquisition that make up the fleet of articulated vehicles and meet the service schedule ordered by Metrobus (Figure 3).

As for the Metrobus Eje 4, under the same guidelines, five companies or agencies were formed in charge of offering the service on existing routes, replacing and considering operators from routes 11,27, 49 and 53 that used to operate on the Eje 4 (Figure 3).

\subsubsection{Legal framework}

Among the regulations that give legal certainty to granted and regulatory companies in consideration of the public transport planning, are the following articles:

Organic Law of the Distrito Federal Public Administration (LOAPDF):

Article 31. To the Ministry of Transport and Roadscorrespondsthe handling of matters related to the full transport development. To set the proper measures and to allow, whenever concessions or permissions that anticipate the legislations and administrative provisions related to public passenger transportproceed.

Article 59. It concerns to the General Direction of Works for Transport. To conduct technological studies and research, to optimize and to modernize the design and construction to the Metro Public Transport System, Metrobus, Electric Transports, Light Rail and Modal Transfer Centerextensions.

Article 58. The General Direction of Urban Servicesresponsibility is: to establish technical criteria and standards topreserve and maintainthe road infrastructure and equipment. To Resurface and give preventive maintenance to the primary road network.

Distrito Federal Road and Transport Law:

Article 2. Metrobus: organization with legal personality.

Article 20. Passenger Local Public Transport System classification, concessioned as well as those provided by the government. Referring to the Distrito Federal Passenger Public Transport Corridor System, Metrobus, Distrito Federal Public Administration Decentralized Public Institution, which has its own legal personality and inheritance in addition to technical and administrative autonomy that in its planning, growth and development shall comply with its instrument of creation, which is part of the Distrito Federal Road and Transport Complete Program and the other applicable legal and administrative arrangements.

Article 29. About concessions. For the passenger transport service concessions within the Distrito Federal Passenger Public Transport Corridors System,it must be adjusted to the requirements that for this purpose are indicated in the respective regulations and administrative agreements issue by the Secretariat and / or through the head of the Metrobus General Direction.

$\underline{\text { Road transport regulations for Distrito Federal passenger transport service: }}$

Chapter Third: About concessions. Section I: Of its granting. Section II: About the term and extension. Section III: About the alienation of concessions.

Chapter Four. About permissions: Section I: of its granting. Section II:about the term and extension.

Chapter V. Concessioner, Licensee and Drivers obligations.

Chapter VI. About the Collective ServiceSection I Passenger Transport Service modalities.

\subsection{Estado de México: Mexibus case}

Although it is a system that is in draft and currently under construction (called Mexibus or Ciudad Azteca-Tecámac corridor), due to the importance of the Estado de Mexico that along with the Distrito Federal form the most populated 
metropolitan area just after Tokyo (Molina, 1999) it is essential to analyze the transport topic in both entities.

\subsubsection{Mexibus system description}

In the Ecatepec de Morelos and Tecámac municipalities, both from Estado de Mexico, were carried out technical and feasibility studies, throwing between the results as follows:

In the hours of peak demand, the public transport service is inadequate, because the existing units are low capacity, tend to modify the authorized routes, which results in poor service delivery and invasion by other routes, generating conflicts and unfair competition. Oversupply of public transport in low-capacity units that creates saturation roads, excessive fuel consumption and high generation of air pollutants. Users spend on average more than three hours a day to travel the length of Ciudad Azteca-Tecámac, resulting in poor quality of life and poor performance in their activities.

In consideration of the foregoing, the agreement was issued by the State executive Mexibus system creates, under the following guidelines:

- It creates the Mass Transit Corridor "Ciudad Azteca-Tecámac" to be treated with high-capacity vehicles, running on the same lanes. The corridor will have a length of $16 \mathrm{~km}$.

- On the stroke of the roadways of Central Avenue Carlos Hank Gonzalez and National Avenue, in the municipality of Ecatepec de Morelos and Tecámac; counting certain intermediate stations, with access controlled by pre-payment system, as well as modal transfer stations.

- The Ministry of Communications and Transportation Secretariat, within the scope of its powers, will undertake the planning, design, construction, rehabilitation, preservation, maintenance, administration, operation, and operation of roads, stations, terminals and other infrastructure to the implementation, development and operation of the corridor, through the granting of the concession titles and respective additional authorizations.

\subsubsection{Actors involved}

Suarez (2009) noted that the corridor involves three key players (Table 9).

The State Government will be responsible for investment in rail confined, ground and road works, supervision of public service, legal security for investments (grants), financial security (surcharge). In the private sector has been a dealer for tender of Infrastructure and dealer operator. The infrastructure is TransbusMex dealer (is a company formed by consortia: Latin AD, Data Concept and Gami group.) (sintesismetro.df.gob.mx/metro/sintesis/pdf/transporte/tra16feb09.pdf). Charge of investment in stations and terminals, collection system, the clearance system and the commercial and advertising. The concession operator is Transmasivo SA de CV (sintesismetro.df.gob.mx/metro/sintesis/pdf/transporte/tra16feb09.pdf), is in charge of the operation of public service, bus acquisition, investment and lock-in workshops, the payment per kilometer and the operation of feeder routes. Transmasivo SA de CV is a company formed from the concessions granted by the Government of Mexico that ran along Central Avenue and National, with 15 companies, which were 13 dealers who eventually formed Transmasivo SA de CV, who addition to their existing bus units will become feeder routes and operate the system with approximately 70 units of buses to provide service in the corridor (Solis, 2009).

\subsubsection{Organization System}

The director general of transport infrastructure of the State of Mexico (Suárez, 2009) has mentioned that the project will have 24 stations and in the corridor plan has defined a business plan that has the following objectives:

- $\quad$ Profitability.

- Economically self-sustaining system.

- Without subsidies.

- Companies autonomous participation.

- Control of the State Government of Mexico.

It relies, considering the following aspects:

- Investment from the State Government.

- Private carriers.

- Investment of $100 \%$ of vehicles by the operators.

- Private investment in infrastructure and equipment. 
- Collection and billing system.

- State Government investment recoverable

The functional structure of the Corridor, which conceptually is considered in its design, is show in Figure 4:

3.3.4 Legal framework

The regulations governing the issue of public transport is structured as a result of the following items and some more than give legal certainty to companies under concession:

Organic Law of Public Administration of the State of Mexico (LOAPEM):

Article 5. The Governor of the State may agree with the Federal Government, other states and the municipalities of the entity, the provision of public services, the execution of works or performing any other purpose of collective benefit.

Article 32. The Ministry of Communications is the unit responsible for developing and managing primary road infrastructure and communications regulation under local jurisdiction, including mass transit systems or high capacity

Article 125. Municipal Organic Law of the State of Mexico. The municipalities will be responsible for the provision, operation, administration and maintenance of municipal public services, considering not limited to, the following: VIII. Public safety and transit.

Regulation of public transport and related services in Mexico State

Chapter II The general scheme of concessions.

Chapter VII of the operation of services.

Chapter VIII The tariff regime.

Chapter IX equipment operators and public transport service.

Article 12. With regard to regular public transport service or discretionary.

Article 14. Types of public transportation passenger.

Article 15. It shall be granted the public service of passenger transport in the following ways: collective, mixed, mass and individual.

Article 16. In reference to what will govern as concessions for the provision of public transport service.

Article 22. Bases of the direct allocation of grants will be made by the transport authority.

\section{Results}

Urgent change of public transport where medium capacity vehicles and buses with old vices disjointed operating archaic ("penny war"), poor quality of service, etc., Leads to increasingly popular paradigm in systems consisting of transit buses Quick, where the institutional factor required for the granting of concessions to private companies formed to operate the service, imposed structural changes among the actors involved, the organization of the system and the regulatory framework. In the three cases mentioned, is manifested primarily involved two actors, the government sector each respective institution, and the dealers routes operators directly affected by the new transport corridor. In this sense, first of all, there is a preference right to return to its dealers and to form associations that operate the corridor, in this way are invited to participate through a competitive bidding and through bus rapid transit.

The organization of the system is constituted from government involvement, respectively, of each entity and participation in concessions to private persons, and reaffirms a shared funding: infrastructure by government units and articulated by the dealers. In the State of Mexico, even projecting a dealer in the infrastructure side of the corridor. The financial operation of the three systems, with external trusts that distribute resources fairly and proportionately to labor agents. The granting of concessions as a legal form provides certainty about their rights and obligations to the operating companies under the guidance of laws and regulatory agencies, so that participants no protection to new competitors that affect the efficiency and financial efficiency of consortia; its structure is a closed system.

Table 10, Table 11, and Table 12 compare the three cases according to the study variables.

\section{Conclusions}

Urban public transport of every city is a key factor for its competitiveness and its inhabitants life quality, so the new sustainable paradigm of transport with bus rapid transit systems has modified the traditional institutional structures of public transport operators by transforming to an operative way based on a "penny war" to a share and business participation. Transformation that has put structural changes between the actors involved sideways where it is observed: 
the concession granted type and the shareholders constitution.In the system organization with: a managing organism formation, the implicated participation type, the functional structure (collection) and thefinancing type. Within the legal framework, its observed: the regulations, the regulator entity, the administration, transport planning and control as a public service and the legal certainty on concessions.

In Metrobus, Mexibus and Optibus cases the affected operators were joined to the new systems routes through concessions. It is observed that these models have government participation scheme through infrastructure fnancing, and even in the Metrobus case in the operation and units through the Public Transport Network (RTP), and private participation in concessions to moral people which finance the articulated vehicles. Unlike Mexibus, there is a scheme with an infrastructure dealer TransbusMex.The collection emphasizes a concentration through trusts operated by external entities where the profits are equitably distributed and by each vehicle traveled kilometer. The regulations concerning the service concession and operation is relatively regulated that provides legal certainty and shields the investment made by constituted moral people, however transparency is missing in the contractual type, in terms of concession time duration, negotiations that are not entirely clear and less public.

Each studied system, forms a tailored suit featuring a business functional operation with institutional aspects of a service that improves the mass public transport quality through the new of bus rapid transit paradigm.

\section{References}

Ardila, A. (2004). Transit Planning in Bogota and Curitiba: Roles in Interaction, Risk and Change. Phd thesis, Boston: MIT.

CISA. (2009). Numeralia, [Online] Available: http://www.ci-sa.com.mx/sistema_transporte/numeralia.php (April 27, 2009).

Embarq the WRI Center for Sustainable Transport CTS. (2009). [Online] Available: http://www.embarq.org/en/project/mexico-city-metrobus. (April 27, 2009).

Espinosa, I. (2008). Modelos de participación mexicanos. Paper presented at the National Congress for the Urban Transport Modernization and Mobility, in the main cities of the country. Mexico City.

German Technical Cooperation/Sustainable Urban Transport Project (GTZ/SUTP), (2003), Sustainable Transport: A Source Book for Policy-makers in Developing Cities Module 3a: Mass Transit options. [Online] Available: http://www.gtz.de/en/themen/28264.htm (April 30, 2009).

Hidalgo. D., Graftieaux, P., \& y Custodio, P. (2007). Ponencia: Sistemas de Buses en América Latina y Asia: Estudios de Caso de Problemas y Áreas de Mejoramiento; Síntesis de Lecciones Aprendidas. Congreso de Transporte Sustentable, Ciudad de México.

Hook, Walter (2005), Non-motorised transport. Eschborn: GTZ - SUTP Sustainable Urban Transport Project. [Online] Available: http://www.sutp.org (March 7, 2009).

Humphrey, F. (1979). The States's Role in Policy Implementation: Transport Policy. U.S: Department of Transportation. Infrastructure National Fund, FONADIN. (2008). Programa de Apoyo Federal al Transporte Urbano Masivo. Paper presented in the IV Sustainable Transport Congress, Mexico City. [Online] Available: http://www.congresotransportesustentable.org/revista.html (May 28, 2009).

Institute for Transportation and Development Policy ITDP, (2007), Bus Rapid Transit Planning Guide. [Online] Available: www.itdp.org (January 13, 2009).

Institutional Gazette CISA, (2008), [Online] Available:http://www.ci-sa.com.mx (July 16, 2008).

Institutional Gazette, CISA, (2008), [Online] Available:http://www.ci-sa.com.mx (July 16,2008).

Iracheta, A. (2006). The necessity of a pubic policy for the transport integrated systems development in big mexican cities. (1ra ed.). Mexico City: El Colegio Mexiquense.

Levinson, H., Zimmerman, S., Clinger, J., Gast, J., Rutherford, S., y Bruhn, E. (2003). Bus rapid transit, volume 1: Implementation guidelines. TCRP Report 90. Washington: US Transit Cooperative Research Program.

Litman, Todd, (2006), Parking taxes: Evaluating options and impacts. [Online] Available: http://www.vtpi.org/tdm/tdm66.htm (November 12, 2009).

Meakin, Richard, (2002), Bus regulation and planning. Eschborn: GTZ - SUTP. Sustainable Urban Transport Project. [Online] Available: http://www.sutp.org (November 12, 2009). 
Menckhoff, G. (2005). Latin American Experience with Bus Rapid Transit. Sustainable Transport Congress Annual meeting - Institute for Transportation Engineers, Melbourne, Australia.

Mereilles, A. (2000). A Review of Bus Priority Systems in Brazil: from Bus Lanes to Busway Transit, Smart Urban Transport Conference, Brisbane 2000.

METRO, (2009), [Online] Available: http://www.metro.df.gob.mx/ (April 27, 2009).

METRO, (2009), Afinan el Metrobus 2. [Online] Available: sintesismetro.df.gob.mx/metro/sintesis/pdf/transporte/tral 6feb09.pdf(April 27, 2009).

Metrobus, (2008), [Online] Available: www.siacsa.com/pdf/brt_metrobus_mx.pdf (January 12, 2009).

Metrobus, (2008a), General Description. [Online] Available: http://www.metrobus.df.gob.mx/ (Jun 23, 2008).

Metrobus, (2008b), Decription. [Online] Available: http://www.metrobus.df.gob.mx/DESCRIPCION.pdf (July 5, 2008).

Metrobus, (2009), [Online] Available: http://www.setravi.df.gob.mx/metrobus/Metrobus.pdf. (November 12, 2009).

Molina L., and Molina, M. (2002). Air Quality In The Mexico Megacity And Integrated Assessment. USA: Kluver Academic Publishers.

Ortúzar, J., and Willumsen, L. (2002). Modelling transport. Uk: John Wiley \& Sons Ltd.

Pagobus, (2009), [Online] Available: http://www.pagobus.com/Optibús.html (March 23, 2009).

Rebelo, Jorge, and Barone, Marcia, (2003), Potential Impact of Metro's Line 4 on Poverty in Sao Paulo Metropolitan Region (SPMR). [Online] Available: http://web.worldbank.org (February 13, 2010).

Report Setravi, (2007). [Online] Available: www.setravi.df.gob.mx/informes/infingstv_sep07V2.pdf (October 7, 2008).

Setravi, (2008), Road and Transport in Distrito Federal. [Online] Available:

http://www.setravi.df.gob.mx/vialidades/transporte_vialidad.html (August 08, 2008).

Setravi, (2008). Bulletin 78. [Online] Available:

http://www.setravi.df.gob.mx/noticias/detalleNoticias.html?id_noticia=741 (April 13, 2009).

Solis, Margarita, (2009), Metrobús in EdoMex Project almost ready. El Financiero, Mexico City. [Online] Available:

sintesismetro.df.gob.mx/metro/sintesis/pdf/transporte/tral 6feb09.pdf(April 13, 2009).

Suárez, Pablo, (2008), Finantial Scheme for Corridors with BRT Systems in Estado de México. Paper presented in the

IV Sustainable Transport Congress, Mexico City. [Online] Available:

http://www.congresotransportesustentable.org/revista.html (March 13, 2009).

Sustainable Transport Center, CTS. (2005). Movilidad Amable, 1,1-90.

Thomas, F. (2001). Bus Rapid Transit. Presentation at The Institute of Transportation Engineers Annual Meeting. Chicago.

Transport and Communication Secretariat, (2007), Development National Plan and the Infrastructure National Plan 2007-2012. [Online] Available: www.sct.gob.mx/uploads/media/Presentacion_SCT-PNI.pdf (April 3, 2009).

United State Federal Transit Administration, (2001), [Online] Available:

http://www.fta.dot.gov/assistance/technology/research_4240.html (March 12, 2009).

Van E., Nijkamp, P. and Vindigni, G. (2003). Analysis of the performance of urban public transport systems in Europe. UNESCO.

Winston, C. (2000). Government Failure in Urban Transportation. Fiscal Studies, 21, (4), 403-425.

Wright Lloyd, (2003), Bus rapid transit. Eschborn: GTZ - SUTP Sustainable Urban Transport Project. [Online] Available: http://www.sutp.org (November 9, 2009).

Wright, Lloyd, and Fjellstrom, Karl, (2003), Mass transit options. Eschborn: GTZ - SUTP Sustainable Urban Transport

Project. [Online] Available: http://www.sutp.org (April 13, 2009). 
Table 1: BRT implementation and planning models institutional aspects

\begin{tabular}{|c|c|}
\hline Model & Institutional Aspects \\
\hline $\begin{array}{lr}\text { German } & \text { Technical } \\
\text { Cooperation/Sustai } \\
\text { nable } & \text { Urban } \\
\text { Transport } & \text { Project } \\
(2003) & \end{array}$ & $\begin{array}{l}\text { During the Design fase (business structure), the following considerations are } \\
\text { underline: } \\
\text { The BRT system must be oriented to competitiveness to the market but limited } \\
\text { inside the market (to compete for the tender contract, but once the company has } \\
\text { been selected it won't have competence from other companies). To create the } \\
\text { businesses structure with the private sector competitiveness basic formula within a } \\
\text { system in control of the private sector. } \\
\text { The system operation in hands on the private sector, the infrastructure (building) } \\
\text { and fee recollection in hands of the private sector. } \\
\text { The transformation of the existing systems, through contractual options such as } \\
\text { franchise, concessions, contract. } \\
\text { The open or close system considering including more operators in the corridor or } \\
\text { just the concessions. } \\
\text { To estimate a regulatory and institutional structure. } \\
\text { To define fee and operation costs. } \\
\text { Incomes distribution on mileage, in an independent system of fee recollection. }\end{array}$ \\
\hline $\begin{array}{l}\text { Sustainable } \\
\text { Transport Centre } \\
(2005)\end{array}$ & $\begin{array}{l}\text { In the new institutional component indicates: } \\
\text { It is essential to generate a new institutional framework in which the participation } \\
\text { and responsibilities of the different private and public entities is redefined. } \\
\text { The creation of a regulation framework that clearly defines the rights and } \\
\text { responsibilities of each system participant that determine the operational, } \\
\text { technical, financial and institutional conditions for the development and system } \\
\text { operation. Governmental decision to create and authority to handle the system. } \\
\text { Conventional system operators' participation into the new scheme, that helps } \\
\text { improve the current operators organizational structure defining the } \\
\text { conventional carriers' role in the BRT system. However, the conventional } \\
\text { carriers' incorporation process to the BRT implies deep changes in your business } \\
\text { organization: from being owner of an individual concession and vehicle to being a } \\
\text { company shareholder. }\end{array}$ \\
\hline $\begin{array}{l}\text { The Institute for } \\
\text { Transportation and } \\
\text { Development } \\
\text { Policy (2007) }\end{array}$ & $\begin{array}{l}\text { In the Business Plan stage states: } \\
\text { Transform from existing systems, considering contractual options such as } \\
\text { franchise, concessions, contract. } \\
\text { A regulatory framework, which legalizes the operation of a partial or complete } \\
\text { system. } \\
\text { A business structure with the basic formula of the private sector competitiveness } \\
\text { within a system with public sector control. The operation in the private sector, } \\
\text { infrastructure (construction) and fare collection in the private sector. } \\
\text { The reengineering of the institutional structure for the entire transport sector } \\
\text { (opportunity) with new responsibilities to manage, regulate and control the } \\
\text { transport efficiently in general. } \\
\text { The creation of a government agency regulatory and responsible for administering } \\
\text { the BRT system, defining its operation through contracts. } \\
\text { Operating and fees costs profitable and unsubsidized. } \\
\text { Funding options for the planning, operation, infrastructure, equipment (vehicles, } \\
\text { fee system) and system maintenance activities. } \\
\text { Marketing that involves the system logo and slogan, campaign strategies and } \\
\text { public education. }\end{array}$ \\
\hline
\end{tabular}

Source: Own elaboration from: Germain Technical Cooperation / Sustainable Urban Transport Project (2003), Sustainable Transport Centre (2005) and The Institute for Transportation and Development (2007). 
Table 2: BRT Definitions

\begin{tabular}{|l|l|}
\hline \multicolumn{1}{|c|}{ Author } & \multicolumn{1}{c|}{ Concept } \\
\hline Thomas (2001). & $\begin{array}{l}\text { Defines BRT as a quick way of transportation that can combine the quality of rail } \\
\text { transport modes and the flexibility of buses }\end{array}$ \\
\hline Levinson et al.,(2003). & $\begin{array}{l}\text { Conceptualizes the BRT as a flexible mode of rapid transit that combines stations, } \\
\text { vehicles with rubber tires, services, lanes and an Intelligent Transportation } \\
\text { System (ITS), integrated components into a system with a strong positive identity } \\
\text { that evokes a unique image }\end{array}$ \\
\hline Wright (2003). & $\begin{array}{l}\text { Considers BRT as high quality transit form, customer-oriented that delivers } \\
\text { speed, comfort and a cost-effective relation on urban mobility }\end{array}$ \\
\hline Sustainable Transport & $\begin{array}{l}\text { BRT conceptualized as a modern mass transport system, designed primarily to } \\
\text { provide mobility needs to users and provide speed, comfort, convenience, low } \\
\text { cost and safety. Is a mass transit system that provides a fast, convenient and cost } \\
\text {-effective urban mobility service. With the use of exclusive lanes for buses, BRT } \\
\text { essentially emulates performance and other attractive features of modern urban } \\
\text { rail transport, but at a fraction of the cost. }\end{array}$ \\
\hline
\end{tabular}

Source: Own elaboration from: the Sustainable Transport Centre (2006), Levinson et al., (2003), Wright (2003) and Thomas (2001).

Table 3: Cities with BRT around the world

\begin{tabular}{|c|c|c|}
\hline Continent & Country & Cities with BRT systems (System name BRT) \\
\hline \multirow[t]{6}{*}{ Asia } & China & Beijing, Hangzhou, Kunming \\
\hline & India & Pune \\
\hline & Indonesia & Jakarta (TransJakar ta) \\
\hline & Japan & Nagoya (Yurikamome Line) \\
\hline & South Korea & Seoul \\
\hline & Taiwan & Taipei \\
\hline \multirow[t]{4}{*}{ Europe } & France & $\begin{array}{l}\text { Caen (Twisto), Clermont Ferrand (Léo 2000), Lyon, Nancy (TVR line 1), } \\
\text { Nantes (Line 4), Nice (Busway), Paris (RN305 busway, Mobilien and Val de } \\
\text { Marne busway), Rouen (TEOR) Toulouse (RN88) }\end{array}$ \\
\hline & Holland & Amsterdam (Zuidtangent), Eindhoven, Utrecht \\
\hline & $\begin{array}{l}\text { United } \\
\text { Kingdom }\end{array}$ & $\begin{array}{l}\text { Bradford (Quality Bus), Crawley (Fastway), Edinburgh (Fastlink), Leeds } \\
\text { (Superbus and Elite) }\end{array}$ \\
\hline & Germany & Essen (O-Bahn) \\
\hline \multirow{6}{*}{$\begin{array}{l}\text { Latin } \\
\text { America } \\
\text { and the } \\
\text { Caribbean }\end{array}$} & Brasil & $\begin{array}{l}\text { Curitiba (Rede Integr ada), Goiânia, (METROBUS ), Por to Alegre (EPTC), } \\
\text { São Paulo, (Interligado) }\end{array}$ \\
\hline & Chile & Santiago (Transantiago) \\
\hline & Colombia & Bogotá (TransMilenio), Pereira (Megabus) \\
\hline & Ecuador & Quito (Trolé, Ecovía, Centr al Norte), Guayaquil (Metrovía) \\
\hline & Guatemala & Ciudad Guatemala (Transmetro) \\
\hline & Mexico & $\begin{array}{l}\text { León (Optibus), Mexico city (Metrobús), Monterrey (Transmetro), Guadalajara } \\
\text { (Macrobus). }\end{array}$ \\
\hline \multirow{2}{*}{$\begin{array}{l}\text { North } \\
\text { America }\end{array}$} & Canada & Ottawa (Transitway) \\
\hline & United States & $\begin{array}{l}\text { Boston (Silver Line Water front), Eugene (EmX), Los Angeles (Orange Line), } \\
\text { Miami (South), Mi ami-Dade Busway), Orlando (Lynx Lymmo), Pittsburgh } \\
\text { (Busway) }\end{array}$ \\
\hline Oceania & Australia & Adelaide (O -Bahn), Brisbane (Busway), Sydney (T-Ways) \\
\hline
\end{tabular}

Source: Own elaboration from: Institute for Transportation and Development Policy, (2007). 
Table 4: Mexico Bus Rapid Transit Projects

\begin{tabular}{|c|c|}
\hline \multicolumn{2}{|l|}{ City / State } \\
\hline & Current BRT systems \\
\hline Leon, Guanajuato & Optibus SIT \\
\hline Mexico City & Metrobús \\
\hline ZM Guadalajara* & Jalisco BRT - Guadalajara’s Macrobús \\
\hline ZM Monterrey* & Transmetro \\
\hline \multicolumn{2}{|r|}{ Planned BRT sistems } \\
\hline $\mathrm{ZMVM}^{* *}$ & $\begin{array}{l}\text { Mexico BRT- Mexibus Metropolitan Corridor Cd. } \\
\text { Azteca-Coacalco-Lechería }\end{array}$ \\
\hline Monterrey, Nuevo Leon & $\begin{array}{l}\text { BRT Monterrey; Public Transport Corridor } \\
\text { Lincoln - Ruiz Cortines }\end{array}$ \\
\hline Chihuahua, Chihuahua & BRT ligero Chihuahua \\
\hline Mexicali, Baja California & BRT ligero Mexicali \\
\hline Oaxaca, Oaxaca & Red de Rutas de Autobuses Rápidos \\
\hline Puebla, Puebla & Red de Autobuses Rápidos Troncales \\
\hline ZMVM, Estado México & $\begin{array}{l}\text { BRT Zinancatepec - Lerma, BRT La Paz- } \\
\text { Ixtapaluca, BRT Cd Azteca - Tecamac, BRT } \\
\text { Chicoloapan - Chimalhuacán - Peñón Viejo }\end{array}$ \\
\hline \multicolumn{2}{|r|}{ BRT systems in expansion } \\
\hline Mexico City & Metrobús (10 additional lines) \\
\hline Leon, Guanajuato & BRT Optibus, 2nd and 3rd routes \\
\hline
\end{tabular}

Source: Own elaboration from: Fondo Nacional de Infraestructura FONADIN (2008).

*ZM: Metropolitan Area. **ZMVM: Mexico's Valley Metropolitan Area

Table 5: Identified actors

\begin{tabular}{|l|l|l|}
\hline 1.Transleón S.A. de C.V. & $\begin{array}{l}\text { 5.Línea Centro Bellavista, S.A. de } \\
\text { C.V. }\end{array}$ & $\begin{array}{l}\text { 9.Transportes Triángulos Dorados } \\
\text { de León, S.A. de C.V. }\end{array}$ \\
\hline $\begin{array}{l}\text { 2.Línea Centro Garita, S.A. de } \\
\text { C.V. }\end{array}$ & $\begin{array}{l}\text { 6.Línea Centro Américas } \\
\text { Deportiva S.A. de C.V. }\end{array}$ & $\begin{array}{l}\text { 10.Transportes Urbanos y } \\
\text { Suburbanos La Joya, S.A. de } \\
\text { C.V. }\end{array}$ \\
\hline $\begin{array}{l}\text { 3.Línea Centro Coecillo, S.A. de } \\
\text { C.V. }\end{array}$ & $\begin{array}{l}\text { 7.Transportes Urbanos León } \\
\text { 2000, S.A. de C.V. }\end{array}$ & $\begin{array}{l}\text { 11.Transportes Urbanos y } \\
\text { Suburbanos de León, S.A. de } \\
\text { C.V. }\end{array}$ \\
\hline $\begin{array}{l}\text { 4.Línea Centro Estación, S.A. de } \\
\text { C.V. }\end{array}$ & $\begin{array}{l}\text { 8.Autobuses Urbanos y } \\
\text { Suburbanos San Juan Bosco, } \\
\text { S.A. de C.V. }\end{array}$ & $\begin{array}{l}\text { 12.Integradora de Transporte } \\
\text { Público General Francisco } \\
\text { Villa, S.A. de C.V. }\end{array}$ \\
\cline { 2 - 3 } & $\begin{array}{l}\text { 13.Transportes Urbanos Los } \\
\text { Ángeles S.A de C.V. }\end{array}$ \\
\hline
\end{tabular}

Source: Own elaboration from: Pagobús, (2009). 
Table 6: Identified Actors

\begin{tabular}{|l|l|}
\hline $\begin{array}{l}\text { 1. } \begin{array}{l}\text { Corredor Insurgentes, S.A } \\
\text { de C.V (CISA) }\end{array} \\
\begin{array}{l}\text { 2. Red de Transporte de } \\
\text { Pasajeros del Distrito } \\
\text { Federal (RTP) }\end{array}\end{array}$ & $\begin{array}{l}\text { According to CISA. It counts with a 75\% } \\
\text { participation in the corridor and it is formed by } 180 \\
\text { associates and a 262 total share. }\end{array}$ \\
this corridor.
\end{tabular}

Source: Own elaboration from: CISA (2009).

Table 7: Identified actors

\begin{tabular}{|l|l|}
\hline $\begin{array}{l}\text { 1. Corredor Insurgentes Sur, } \\
\text { Rey Cuauhtémoc S.A de C.V, } \\
\text { (RECSA) }\end{array}$ & $\begin{array}{l}\text { The RECSA company consists of } 137 \text { collective transport } \\
\text { dealers of routes 1 and } 76 \text { that served in the extended area of } \\
\text { the corridor, becoming a trading company toobtain the } \\
\text { concession. Their participation in the service operation is of } \\
75 \% \text {. }\end{array}$ \\
\hline $\begin{array}{l}\text { 2. Red de Transporte de de } \\
\text { Pasajeros" Red de Transporte } \\
\text { de Pasajeros del Distrito } \\
\text { Federal (RTP) }\end{array}$ & The authorization to RTP represents the remaining $25 \%$. \\
\hline
\end{tabular}

Source: Own elaboration from: Gaceta CISA, March 2008 and January 2008.

Table 8: Identified actors

\begin{tabular}{|c|c|}
\hline $\begin{array}{l}\text { 1. GM4 - } 17 \text { de Marzo, S.A. de } \\
\text { C.V }\end{array}$ & $\begin{array}{l}\text { It is the company with the largest share }(27.7 \%) \text {, it was } \\
\text { allocated with } 20 \text { articulated buses, } 10 \text { of which are operating } \\
\text { as support to the Metrobus in line } 1 .\end{array}$ \\
\hline $\begin{array}{l}\text { 2. Corredor Tepalcates } \\
\text { Tacubaya, S.A de C.V } \\
\text { (CTTSA) }\end{array}$ & With a 16 articulated units allocation (22.2\%). \\
\hline $\begin{array}{l}\text { 3. Corredor Oriente Poniente, } \\
\text { S.A de C.V (COPSA). }\end{array}$ & $\begin{array}{l}\text { Composed by dealers from routes } 49,27 \text { and } 53 \text { and allocated } \\
\text { with } 15 \text { brand articulated units }(20.8 \%) \text { to provide transport } \\
\text { service. }\end{array}$ \\
\hline $\begin{array}{l}\text { 4. Transportes SAJJ S.A DE } \\
\text { C.V. }\end{array}$ & $\begin{array}{l}\text { Formed by dealers from route } 11 \text { participating with } 9 \text { buses } \\
(12.5 \%) \text {. }\end{array}$ \\
\hline $\begin{array}{l}\text { 5. Red de Transporte de } \\
\text { Pasajeros del Distrito Fe }\end{array}$ & $\begin{array}{l}\text { It is the government representation that has } 12 \text { articulated units } \\
(16.6 \%) \text {. }\end{array}$ \\
\hline
\end{tabular}

Source: Own elaboration from: METRO, (2009).

Table 9: Identified actors

\begin{tabular}{|l|l|}
\hline 1. State Government. & $\begin{array}{l}\text { Arrange for the investment in rail confined, ground and road } \\
\text { works, supervision of public service, legal and financial security }\end{array}$ \\
\hline 2. Private Initiative & $\begin{array}{l}\text { There has been a dealer for tender of Infrastructure } \\
\text { (TransbusMex) and a dealer operator (Transmasivo). }\end{array}$ \\
\hline $\begin{array}{l}\text { 3. Current carriers } \\
\text { (company). }\end{array}$ & $\begin{array}{l}\text { Transmasivo that is a corporation from the concessions granted by } \\
\text { the Government of Mexico that ran along Central Avenue and } \\
\text { National, with 15 companies, which were 13 dealers }\end{array}$ \\
\hline
\end{tabular}

Source: Own elaboration from: Suarez, (2009) and Solis, (2009). 
Table 10: Comparison between the actors involved transport systems: Metrobus, and Optibus Mexibus.

\begin{tabular}{|c|c|c|c|}
\hline $\begin{array}{c}\text { Actors } \\
\text { Involved } \\
/ \text { City }\end{array}$ & $\begin{array}{c}\text { Metrobus: } \\
\text { Ciudad de Mexico }\end{array}$ & $\begin{array}{l}\text { Mexibus Estado de } \\
\text { Mexico }\end{array}$ & $\begin{array}{c}\text { Optibus: } \\
\text { Leon, Guanajuato }\end{array}$ \\
\hline $\begin{array}{l}\text { Contract } \\
\text { Option }\end{array}$ & $\begin{array}{l}\text { Through public bidding to } \\
\text { moral person. }\end{array}$ & $\begin{array}{l}\text { Through public bidding } \\
\text { to moral person. }\end{array}$ & $\begin{array}{l}\text { Through public bidding to moral } \\
\text { person. }\end{array}$ \\
\hline $\begin{array}{l}\text { Shareholder } \\
\text { Identificatio } \\
\mathrm{n}\end{array}$ & $\begin{array}{l}\text { Metrobus Insurgentes: } \\
\text { Current shareholders are } \\
\text { individual concessionaires } \\
\text { who conformed Route 2: } \\
\text { - 25\%, by the transport } \\
\text { company called } \\
\text { Passenger Transport } \\
\text { Network (RTP). } \\
\text { - 75\% by Corredor } \\
\text { Insurgentes, S.A de C.V } \\
\text { (CISA). } \\
\text { Metrobús Insurgentes Sur: } \\
\text { - Corredor Insurgentes } \\
\text { Sur, Rey Cuauhtémoc } \\
\text { S.A de C.V, (RECSA): } \\
\text { 75\% service operation } \\
\text { participation. } \\
\text { - Red de Transporte de } \\
\text { Pasajeros" Distrito } \\
\text { Federal Passenger } \\
\text { Transport Network } \\
\text { (RTP): The } \\
\text { authorization to RTP } \\
\text { represents the remaining } \\
\text { 25\%. } \\
\text { Metrobús Eje 4 Sur: } \\
\text { Current shareholders are } \\
\text { the individual } \\
\text { concessionaires who used } \\
\text { to form Routes } 11,27,49 \\
\text { and 53: } \\
\text { - GM4 - 17 de Marzo, } \\
\text { S.A. de C.V. (27.7\%). } \\
\text { - Corredor Tepalcates } \\
\text { Tacubaya, S.A de C.V } \\
\text { (CTTSA). (22.2\%). } \\
\text { - Corredor Oriente } \\
\text { Poniente, S.A de C.V } \\
\text { (COPSA). (20.8\%). } \\
\text { - Transportes SAJJ S.A } \\
\text { DE C.V. (12.5\%). } \\
\text { - Red de Transporte de } \\
\text { Pasajeros del Distrito } \\
\text { Federal. (RTP) (16.6\%). }\end{array}$ & $\begin{array}{l}\text { Operating } \\
\text { Concessionaire } \\
\text { Transmasivo S.A de } \\
\text { C.V: Constituted } \\
\text { company from } \\
\text { concessions granted to } \\
15 \text { companies by } \\
\text { Estado de Mexico's } \\
\text { Government that ran } \\
\text { along Avenida Central } \\
\text { and Avenida National } \\
\text { from which were } 13 \\
\text { dealers. } \\
\text { Concesionario } \\
\text { Infraestructura: } \\
\text { TransbusMex: } \\
\text { Company formed by } \\
\text { the consortia: Latin } \\
\text { AD, Data Concepto } \\
\text { and Grupo Gami. }\end{array}$ & $\begin{array}{l}\text { In } 2000 \text { thirteen companies that } \\
\text { integrate the Leonurban transport } \\
\text { coordinator decide to participate in the } \\
\text { Transport Integrated System (SIT). } \\
\text { 1. Transleón S.A. de C.V. } \\
\text { 2. Línea Centro Garita, S.A. de C.V. } \\
\text { 3.Línea Centro Coecillo, S.A. de C.V. } \\
\text { 4. Línea Centro Estación, S.A. de C.V. } \\
\text { 5. Línea Centro Bellavista, S.A. de } \\
\text { C.V. } \\
\text { 6. Línea Centro Américas Deportiva } \\
\text { S.A. de C.V. } \\
\text { 7. Transportes Urbanos León 2000, } \\
\text { S.A. de C.V. } \\
\text { 8.Autobuses Urbanos y Suburbanos } \\
\text { San Juan Bosco, S.A. de C.V. } \\
\text { 9. Transportes Triángulos Dorados de } \\
\text { León, S.A. de C.V. } \\
\text { 10. Transportes Urbanos y Suburbanos } \\
\text { La Joya, S.A. de C.V. } \\
\text { 11. Transportes Urbanos y Suburbanos } \\
\text { de León, S.A. de C.V. } \\
\text { 12. Integradora de Transporte Público } \\
\text { General Francisco Villa, S.A. de C.V. } \\
\text { 13. Transportes Urbanos Los Ángeles } \\
\text { S.A de C.V. } \\
\text { En Agosto de ese mismo año, se } \\
\text { decidió la conformación de más de una } \\
\text { empresa para la operación de las rutas } \\
\text { troncales, lo que dio origen a cuatro } \\
\text { nuevas organizaciones: } \\
\text { 1.Red Optibús Norte, S. A. de C. V. } \\
\text { 2.Red Optibús Sur, S. A. de C. V. } \\
\text { 3.Red Integral Optibús, S. A. de C. V. } \\
\text { 4.Red Optibús Oriente, S. A. de C. V. }\end{array}$ \\
\hline
\end{tabular}

Source: Own elaboration. 
Table 11: Comparative organization of the system between BRT: Metrobus, Mexibus and Optibus.

\begin{tabular}{|c|c|c|c|}
\hline $\begin{array}{c}\text { System } \\
\text { Organization } \\
\text { /City } \\
\end{array}$ & $\begin{array}{l}\text { Metrobús: } \\
\text { Mexico City }\end{array}$ & Mexibus: Estado de México & $\begin{array}{c}\text { Optibús: } \\
\text { León, Guanajuato }\end{array}$ \\
\hline $\begin{array}{l}\text { Managing } \\
\text { body }\end{array}$ & Metrobus & TransbusMex & PagoBus \\
\hline $\begin{array}{l}\text { Participation } \\
\text { Type }\end{array}$ & $\begin{array}{l}\text { 1. Private participation } \\
\text { through concession to } \\
\text { moral person. } \\
\text { 2. Government participation } \\
\text { in operation and } \\
\text { infrastructure. }\end{array}$ & $\begin{array}{l}\text { 1. State Government. } \\
\text { 2. Private Initiative. } \\
\text { 3. } \text { Current carriers (company) }\end{array}$ & $\begin{array}{l}\text { 1.Private participation through a } \\
\text { consortium. } \\
\text { 2. Government participation in } \\
\text { infrastructure. }\end{array}$ \\
\hline $\begin{array}{l}\text { Functional } \\
\text { Structure }\end{array}$ & $\begin{array}{l}\text { Through Metrobus figure, } \\
\text { which through a company } \\
\text { collects tariff revenues, which } \\
\text { through a trust are concentrated } \\
\text { and distributed equitably and } \\
\text { proportionately to the respective } \\
\text { partner carriers. }\end{array}$ & $\begin{array}{l}\text { The collection will be deposited in } \\
\text { a private trust through financial } \\
\text { institutions and it will have a } \\
\text { contingency fund, backed by a } \\
\text { Master Trust. The revenues are } \\
\text { distributed to the dealer operators, } \\
\text { suppliers and related services } \\
\text { dealers as regulators and to the } \\
\text { collecting company. }\end{array}$ & $\begin{array}{l}\text { It is managed by theorganism } \\
\text { called Pago Bus, a controlled } \\
\text { collection trust, responsible for the } \\
\text { distribution of the economic } \\
\text { resources in an equitable and } \\
\text { proportional way between the } \\
\text { transport companies. }\end{array}$ \\
\hline $\begin{array}{l}\text { Financing } \\
\text { form }\end{array}$ & $\begin{array}{l}\text { - The City Government } \\
\text { performs the planning, } \\
\text { coordination, stewardship } \\
\text { and management as well as } \\
\text { the construction financing } \\
\text { and the corridor } \\
\text { infrastructure maintenance. } \\
\text { - On their turn the corridor } \\
\text { concesionaries have } \\
\text { financially contributed to the } \\
\text { units acquisition that } \\
\text { conform the articulated } \\
\text { vehiclesfleet and meet the } \\
\text { service schedule ordered by } \\
\text { Metrobus in charge of } \\
\text { offering the service on } \\
\text { existing routes. }\end{array}$ & $\begin{array}{l}\text { The State Government will: } \\
\text { will be in charge of: the investment } \\
\text { in confined rail, ground and road } \\
\text { works, the supervision of the public } \\
\text { service, the legal security for } \\
\text { investments (grants) and financial } \\
\text { security (rate). } \\
\text { In private iniciative are two } \\
\text { concessionaires: } \\
\text { Infrastructure } \\
\text { TransbusMex Concessionaire: } \\
\text { Stations and terminals investment. } \\
\text { Collection system. Dispatch system. } \\
\text { Commercial and advertising } \\
\text { explotation. Operator } \\
\text { Concessionaire: Transmasivo S.A } \\
\text { of C.V. } \\
\text { Buses acquisition. Confinement and } \\
\text { workshops investment. Pay per } \\
\text { travelled kilometer. Feeder routes } \\
\text { operation. }\end{array}$ & $\begin{array}{l}\text { - The City Government performs } \\
\text { the planning, coordination and } \\
\text { management as well as the } \\
\text { construction and maintenance of } \\
\text { the integrated system } \\
\text { infrastructure. } \\
\text { - The complete system } \\
\text { concessionaires financially } \\
\text { participate with the renewal and } \\
\text { maintenance of the units that } \\
\text { conform the vehicles fleet of } \\
\text { Optibús system. }\end{array}$ \\
\hline
\end{tabular}

Source: Own elaboration.

Table 12: Legal framework comparison between transport systems: Metrobus, Mexibus and Optibus.

\begin{tabular}{|c|c|c|c|}
\hline $\begin{array}{l}\text { Legal } \\
\text { Framework } \\
\text { /City }\end{array}$ & $\begin{array}{l}\text { Metrobús: } \\
\text { Mexico City }\end{array}$ & Mexibus Estado de México & $\begin{array}{c}\text { Optibús: } \\
\text { León, Guanajuato }\end{array}$ \\
\hline Normativity & $\begin{array}{l}\text { - Distrito Federal Public } \\
\text { Administration Organic } \\
\text { Law (LOAPDF). } \\
\text { - Distrito Federal road and } \\
\text { transport Law }\end{array}$ & $\begin{array}{l}\text { - Estado de Mexico Public } \\
\text { Administration Organic Law } \\
\text { (LOAPEM). } \\
\text { - Estado de Mexico Municipal } \\
\text { Organic Law } \\
\text { - Estado de Mexico Public Transport } \\
\text { Regulation and Related Services. }\end{array}$ & $\begin{array}{l}\text { - Estado de Guanajuato } \\
\text { Public Administration } \\
\text { Organic Law } \\
\text { (LOAPGTO). } \\
\text { - Leon, Guanajuato } \\
\text { Municipal Transport Law }\end{array}$ \\
\hline $\begin{array}{l}\text { Regulatory } \\
\text { Entity }\end{array}$ & $\begin{array}{l}\text { - Distrito Federal } \\
\text { Government. } \\
\text { - Road and Transport } \\
\text { Secretariat (Setravi). }\end{array}$ & $\begin{array}{l}\text { Estado de México Government. } \\
\text { Transport and Communication } \\
\text { Secretariat (SCT). } \\
\text { Estado de Ecatepec and Tecámac } \\
\text { Municipality }\end{array}$ & $\begin{array}{l}\text { Estado de Guanajuato } \\
\text { Government. León, } \\
\text { Guanajuato Municipality and } \\
\text { Councils. }\end{array}$ \\
\hline
\end{tabular}




\begin{tabular}{|c|c|c|c|}
\hline $\begin{array}{l}\text { Transport } \\
\text { control as } \\
\text { public service } \\
\text { Administration, } \\
\text { Planning and } \\
\text { Control }\end{array}$ & $\begin{array}{l}\text { Mainly (LOAPDF): } \\
\text { Article } 31 \text { and } 59 .\end{array}$ & 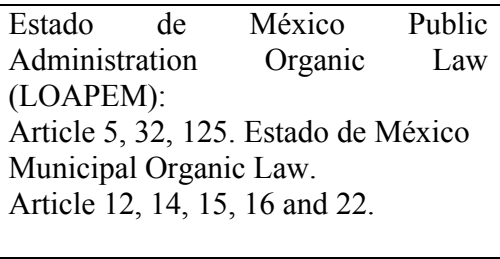 & $\begin{array}{l}\text { Estado de Guanajuato Public } \\
\text { Administration Organic Law } \\
\text { (LOAPGTO): } \\
\text { Article 141. } \\
\text { Guanajuato León, } \\
\text { Regulation: } \\
\text { Article 2, 6, 12, 14, 15.- }\end{array}$ \\
\hline $\begin{array}{l}\text { Legal certainty } \\
\text { in concessions }\end{array}$ & $\begin{array}{l}\text { Distrito Federal Road and } \\
\text { Transport Law. } \\
\text { Article 2, 20, 24, } 25 \text { and } 29 . \\
\text { Distrito Federal passenger } \\
\text { transport } \\
\text { Regulation. }\end{array}$ & $\begin{array}{l}\text { Estado de México Public Transport } \\
\text { and Related Services Regulation. } \\
\text { Article } 15,16 \text { and } 22 \text {. }\end{array}$ & $\begin{array}{l}\text { León, Guanajuato Municipal } \\
\text { Transport Regulation: } \\
\text { Article 16, 17, 20, 21, 55, } \\
100 \text { and } 106 .\end{array}$ \\
\hline
\end{tabular}

Source: Own elaboration.

Informal Transport ServicesTransporte

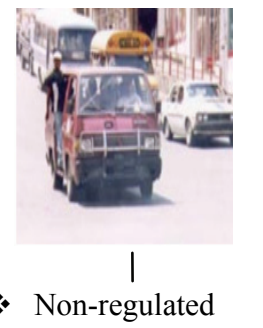
operators.

* Taxi type services.

* Poor service.

* Relatively insecure.

* Small and antique vehicles.
Conventional Buses Services

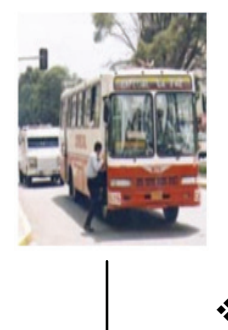

* Standard buses.

* Fee collection at boarding the vehicle.

* Corridor single services/lanes separation.

* Very basic stations.
Basic BRT

BRT
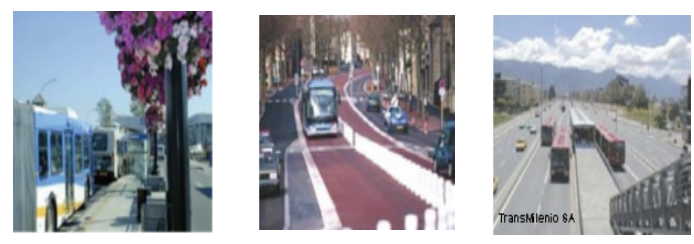

Lanes

separation/

- Fee collection and verification in pre boarding.

* High quality stations.

* Clean technology vehicles.

* Identity marketing.
* Private or public operation.

* Generally subsidized.

* Fee collection at vehicle boarding.

* Poor service.

* Very basic or in post stations.

* Standard buses.
Some ways of priority at bus passing without full lane separation.

* Travelling time improvement.

* High Quality stations.

* Clean technology vehicles.

* Identity marketing.
* Quality service similar to the subway.

* Corridors and routes integrated network.

* High quality closed stations.

* Pre boarding fee verification and collection.

* Frequent and fast services.

* Modern vehicles.

* Identity marketing.

* High quality client services.

Figure 1: Spectrum of quality public transport buses Source: Institute for Transportation and Development Policy, (2007). 


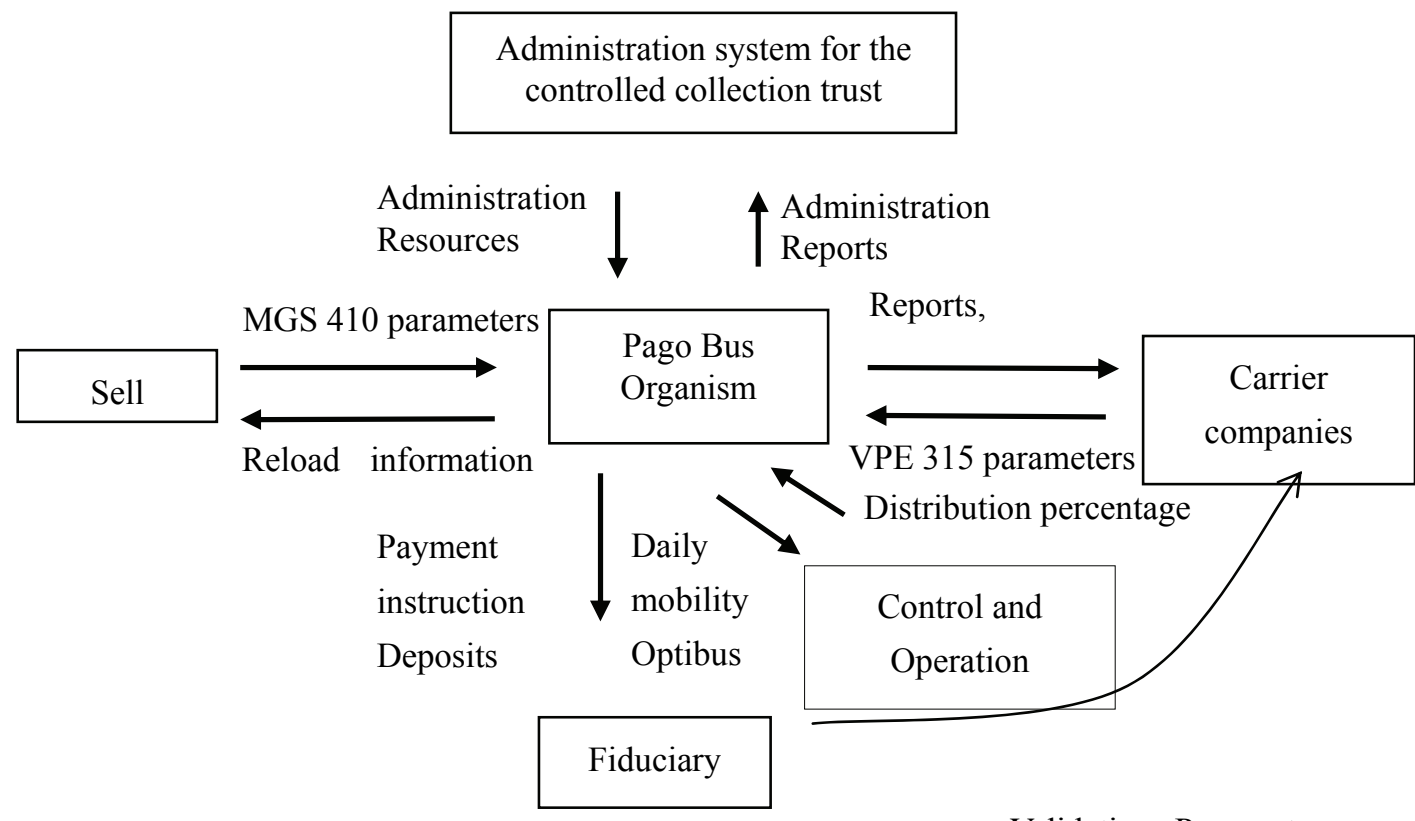

Figure 2: Optibús Functional Structure

Source: Espinosa, (2008).

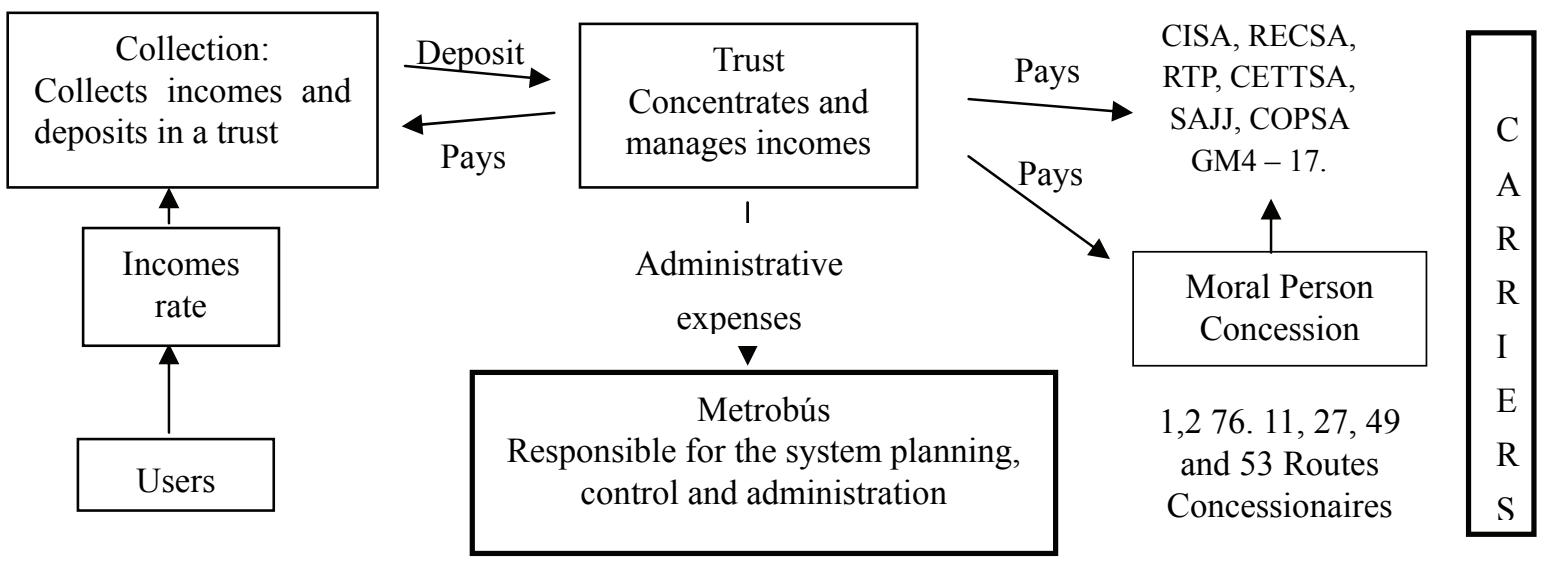

Figure 3: Functional Structure Metrobus Insurgentes, Insurgentes Sur and Eje 4 Sur. Source:Own elaboration from: Metrobus (2008a, 2008b). 